\title{
Personal and environmental hygiene in Norwegian nursing homes
}

\author{
Ingrid Sie ${ }^{1}$, Margrete Thorstad ${ }^{1}$, Bjørg Marit Andersen ${ }^{1,2}$ \\ 1. Diakonova University College, Oslo City, Norway. 2. Department of Hospital Infections, Oslo University Hospital-Ullevål, \\ Norway
}

Correspondence: Bjørg Marit Andersen. Address: Department of Hospital Infections, Oslo University Hospital - Ullevål, Oslo 0407, Norway. Email: bomarand@hotmail.com

Received: September 20, 2011

Accepted: November 30, $2011 \quad$ Published: February 1, 2012

DOI : $10.5430 /$ jnep.v2n1p71

URL: http://dx.doi.org/10.5430/jnep.v2n1p71

\begin{abstract}
The prevalence of nosocomial infections in Norwegian nursing homes is still high (ca 7\%) and MRSA-problems are increasing in nursing homes. Environmental hygiene and hygienic use of uniforms may play an important role concerning transmission of nosocomial infections. Most nursing homes in Oslo have written routines for floor cleaning and for the use of uniforms. However, while the procedures for the daily use and change, and washing of the uniforms was followed by all the staff, only $50 \%$ of the institutions seemed to implement in practice the written routines for environmental cleaning. The lack of daily cleaning in nursing homes may be associated with an increased risk of nosocomial infections.
\end{abstract}

\section{Key words}

Infection control, Nursing homes, Floor cleaning, Use of uniforms

\section{I ntroduction}

When Florence Nightingale nursed soldiers in a hospital during the Crimean war, the mortality rate dropped from $42.7 \%$ to $2.2 \%$ in about half a year ${ }^{[1]}$. Florence Nightingale introduced several important hygiene rules, such as floor cleaning and personal hygiene for the employee. Today, environmental and personal hygiene, including hand hygiene, are still important measures to prevent serious infectious diseases in healthcare ${ }^{[2-13]}$.

Microbes may survive in the environment for months, like methicillin-resistant Staphylococcus aureus (MRSA),

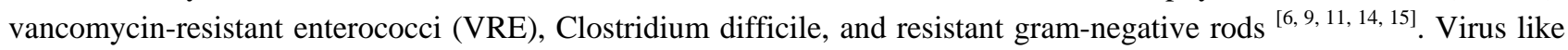
noro-, entero-, adeno- and even influenza virus, may survive for longer periods in the patient's environment ${ }^{[14]}$.

Cleaning is the removal of visible e.g. organic and inorganic material from objects and surfaces and normally is accomplished manually or mechanically using water with detergents or enzymatic products ${ }^{[5,10,12,16-19]}$. However, extensive contamination of the environment with bacteria or virus may not be eliminated by standard cleaning methods. In such situations, decontamination has to be done with liquid disinfectants or hydrogen peroxide gas ${ }^{[20-23]}$.

Nursing homes may have large and increasing reservoirs of resistant bacteria and other contagious microbes that may be transmitted by contact, environment and even via air ${ }^{[24-38]}$. Patients and staff may be affected, and the healthcare workers 
(HCW) may become carriers of pathogenic microbes on their uniforms, hands and other body sites, and from there transmit the agents further to the environment ${ }^{[8,22,30,32-34]}$.

According to the Norwegian Communicable Disease Act with Guidelines, all healthcare institutions, including nursing homes are required to have written routines for infection control work, like registering of infections, hand hygiene, use of uniforms, cleaning, use of personal protective equipment and isolation ${ }^{[39]}$.

The aim of this study is to describe general hygienic routines in nursing homes, like the floor cleaning procedures and the use of staff uniform during work.

\section{Material and methods}

\subsection{Study design}

This study was a point prevalence study, a cross-sectional questionnaire study among the employee in Norwegian nursing homes, concerning infection control problems and practical implementation of hygienic routines.

\subsection{Nursing homes}

Oslo City has just over 500,000 inhabitants and a total of 55 nursing homes with 4400 beds. All 55 nursing homes were invited to participate in the study and 42 institutions agreed to participate. The nursing homes were both private (profit and non-profit) and community-owned, with different sizes from 20-187 beds. Each nursing home was divided in units with 10 -25 patients in each unit, providing 24 hours care.

\subsection{Personnel}

Leaders of the institutions and the sisters (one leading, enrolled nurse at each ward) worked daytime, while the nursing staff (enrolled nurses or nurse-assisting staff) worked on three-divided shift. The sisters administered the ward with the survey of daily routines, the needs for personnel in work, admittance of patients, contact with the practitioner and so on. The nursing staff nursed the patients, distributed medicines and provided treatment ordered. Only $19 \%$ of the nursing staff was enrolled nurses. The basic nurse education is a three-year healthcare education in a university college or high school, resulting in a bachelor degree. Further education is in specialties like for instance within surgery, pediatrics, obstetrics and intensive care. Most nurses and sisters in nursing homes have only the basic nurse education. The nurse assistants were: special nurse-assistants with two years of basic education in healthcare, nurse students, medical students, and persons without any healthcare education. In all, 32\% of the nursing staff had no healthcare education at all and they did not participate in this study.

\subsection{Questionnaires and staff study}

In this part of the study, the questionnaires were distributed to the nursing staff and to the ward sisters. The nurse responsible for infection control delivered the questionnaire to the respondents she chose among the personnel with healthcare education at her institution or unit. The nursing staffs were selected in a casual manner by factors like the persons being on work that day and the persons that had time to answer. She also delivered a questionnaire to the ward sister at each ward. Some questions were not the same to the sisters and to the nursing staff because of the different responsibilities and work situations of the sisters and staff. Other questions could be similar to uncover different opinions associated with their work position, responsibility and experience. The respondents were asked about knowledge and practice concerning infection control programme, infection control routines and hand hygiene, and knowledge, practice and problems concerning MRSA, as shown earlier ${ }^{[35,36]}$. This article is based on data from the questionnaires among ward sisters and nursing staff about infection control routines, floor cleaning procedures and uniform use. 


\subsection{I nformed consent and ethical aspects}

Agreements of this study were received from the Directors of the different health districts of Oslo City, in charge of the nursing homes. The Community Infection Control of Oslo City was helpful concerning contact with the nursing homes. The study was voluntary and made anonymously for all who participated. The data were collected anonymously and closed for each person, without signature or name and without information on which nursing home the respondents were working. The name of the nursing home where the answers came from was also anonymous. No patient-associated data were collected. The investigators had no possibility to find out which nursing home the answers came from. The ethical aspects and informed consent were therefore taken care of.

\subsection{Cleaning routines}

The County Department of Nursing Homes in Oslo has recommended a general plan for daily cleaning of nursing homes in Oslo ${ }^{[41]}$. The plan includes cleaning methods and frequency of cleaning with grades according to the risk of infection transmission (see Table 1). Three different mopping methods are recommended used on the floor: wet, moist and dry mopping. The plan is divided into "ordinary cleaning" (horizontal areas from the floor up to the high of $1.80 \mathrm{~m}$ ), programmed cleaning (with a preset frequency - in risk areas) and required cleaning (when needed). The cleaner has the responsibility of controlling the quality of the work. A combination of the methods is used to secure a good clean quality and an aesthetic and hygienic indoor environment. In addition, periodic cleaning is like washing all rooms more thoroughly; walls, ceilings, furniture etc, every year or more often. This plan recommends that the floor of the patients' rooms should be cleaned by moist mopping two times a week and by dry mopping two times a week. Methods for decontamination of rooms after infections are not included in the plan.

Table 1. Frequency of ordinary cleaning, related to risk of transmission of microbes

\begin{tabular}{|c|c|c|}
\hline Type of risk area & Room type & $\begin{array}{l}\text { Cleaning Frequency } \\
\text { days/week }\end{array}$ \\
\hline \multirow[t]{8}{*}{ High risk area } & Toilet on patients room & 7 \\
\hline & Infected patients room & 7 \\
\hline & Common toilet for residents & $2 \times 7$ \\
\hline & Handicap toilet & $2 \times 7$ \\
\hline & Bathroom-common & 5 \\
\hline & Disinfection room & 5 \\
\hline & Kitchen & 5 \\
\hline & Room for dirty linen & 5 \\
\hline \multirow[t]{5}{*}{ Medium risk area } & Patient room & 4 \\
\hline & Clean linen room & 4 \\
\hline & Meeting room & 5 \\
\hline & Treatment room & 4 \\
\hline & Dining-room & 4 \\
\hline \multirow[t]{3}{*}{ Low risk area } & Bathroom-personnel & 5 \\
\hline & Wardrobes & 4 \\
\hline & Physicians office & 1 \\
\hline
\end{tabular}




\subsection{Uniform use}

The County Department of Nursing Homes is recommending a written routine for uniform with daily change of the uniform and washing of uniforms in the institutions' laundry. The institution manager is responsible for written uniform routines in the institution and for use of personal protective equipment. The manager has the responsibility for the knowledge, implementation and control of uniform use among the staff members. The uniforms are washed at $85^{\circ} \mathrm{C}$ for at least 10 minutes at the institutions own laundry. Jewellery, piercing and wristwatch are not allowed to use when wearing uniform. Special gowns should be used when caring for patients with infections.

Statistical data were analysed by SPSS 15.0 (SPSS Inc., Illinois).

\section{Results}

Nursing homes 42 (76\%) nursing homes with approximately 3350 patients participated in this study.

Questionnaires and demographic data Of the 486 questionnaires delivered to ward sisters and nursing staff at the 42 nursing homes in Oslo, 355 (73\%) were completed and returned. Among respondents, 229 were nursing staff and 126 were sisters (see Table 2). Nearly all (90\%) the nursing staff was women; $51.5 \%$ were nurses and $44.5 \%$ nurse practitioners. The mean age was 41 years for the nursing staff and 46 for the sisters, and both groups had a mean of 7 years employment in the work position (see Table 2). All had positions of 50\% full-time employment or more, and $79 \%$ of the nursing staff had $100 \%$ full-time positions. Altogether, 41(18\%) were engaged in work at several institutions during the same period.

Table 2. Respondents-demographic data

\begin{tabular}{lll}
\hline Respondents & $\begin{array}{l}\text { Nursing staff } \\
(\mathbf{N = 2 2 9 )}\end{array}$ & $\begin{array}{l}\text { Sisters } \\
(\mathbf{N = 1 2 6 )}\end{array}$ \\
\hline Nurses & $51.5 \%$ & $87 \%$ \\
Enrolled nurses & $44.5 \%$ & $13 \%$ \\
Others & $4 \%$ & $14 \%$ \\
Men & $10 \%$ & $86 \%$ \\
Women & $90 \%$ & 46 \\
Age in years; Mean & 41 & $27-68$ \\
Variation & $20-78$ & 7 \\
Time in position: mean & 7 & $0-22$ \\
Variation & $0-32$ & \\
$100 \%$ position & $79 \%$ & \\
$>50 \%$ position & $100 \%$ & \\
\hline
\end{tabular}

Infection control guidelines/procedures According to the respondents, 115/126 sisters (94\%) and 215/229 nursing staff (96\%) reported that they had written routines for infection control, and the majority of them (ca 75\%) had also a person responsible for infection control in the ward.

Cleaning of the floor - frequency According to the ward sisters, most nursing homes in Oslo had written routines for how to clean the floors in the unit. The cleaning frequency was however variable. Among the 108 sisters that answered the question, $11 \%$ reported that the patients' rooms was cleaned 7 days a week, 38\% reported cleaning 5 days a week and $51 \%$ reported cleaning only 3 days a week (see Figure 1). 


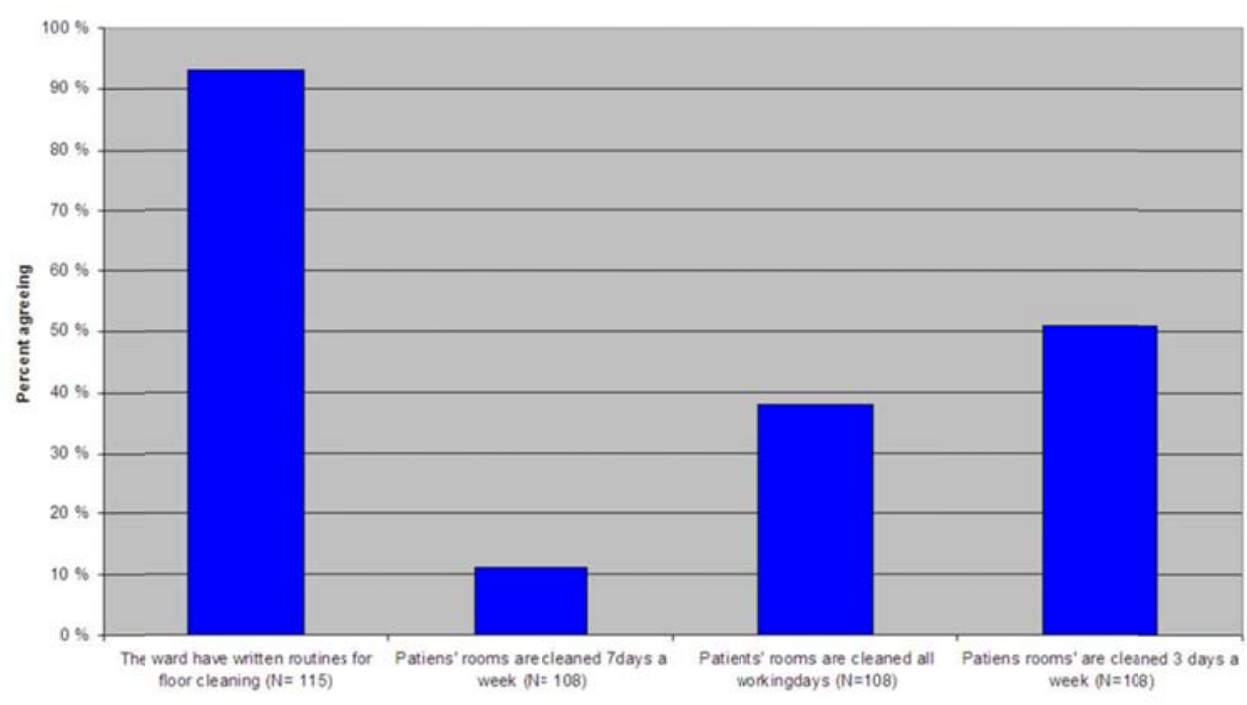

Figure 1. Floor cleaning procedures-information from sisters at nursing homes in Oslo

The method of floor cleaning Moist mopping was the most common method used for daily cleaning, as reported by the nursing staff (88\%) and sisters (96\%)(see Figure 2). However, cleaning with soap and water was also a common method for cleaning floors in patients' rooms, as reported by $40 \%$ of all personnel, including sisters. Also dry and wet mopping was often (65-80\%) used for cleaning of the patients' rooms. The answers from the sisters showed a little higher percent for all mopping methods, but still a good congruence with those from the nursing staff. However, $10-21 \%$ of the personnel did not know which cleaning methods that were used on their work place.

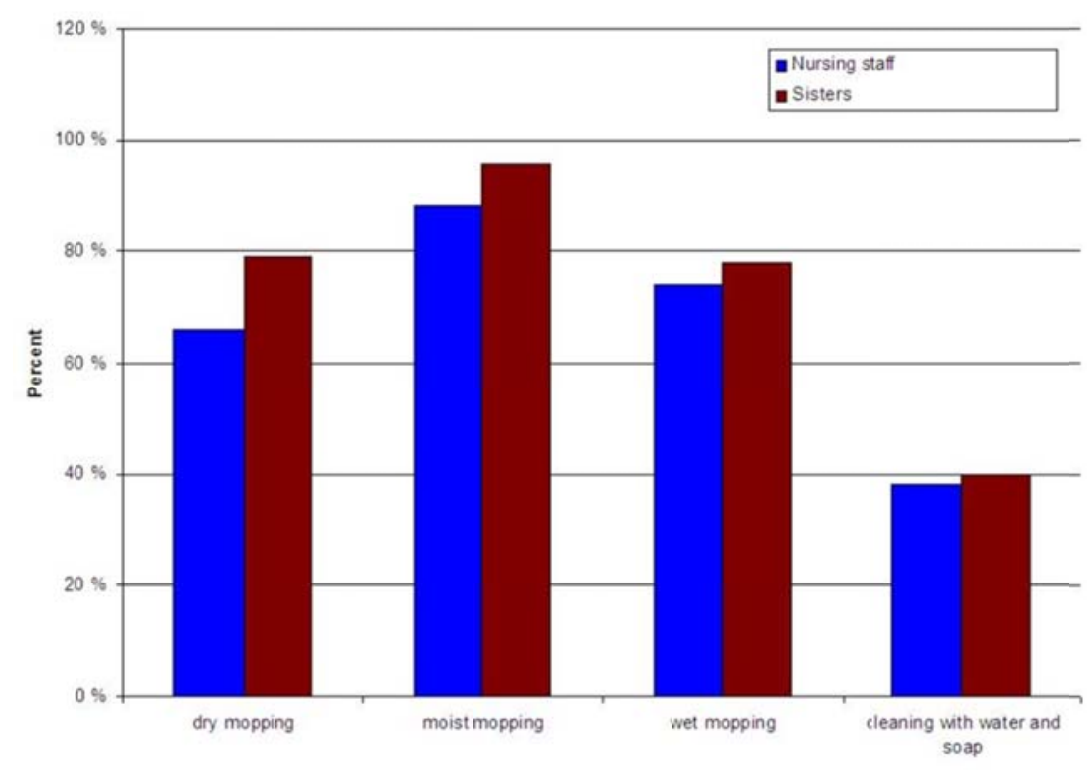

Figure 2. Cleaning methods used in nursing homes in Oslo

The use of uniforms According to the ward sisters, most wards had written routines for the use of uniforms (see Figure 3). All uniforms were owned and cleaned by the institutions and were changed daily. One respondent commented that the uniforms could even be changed during the day if contaminated. The study was strengthened by the fact that the sisters (97\%) and the nurses and nurse practitioners (96\%) reported the same procedure of changing the uniforms daily. 


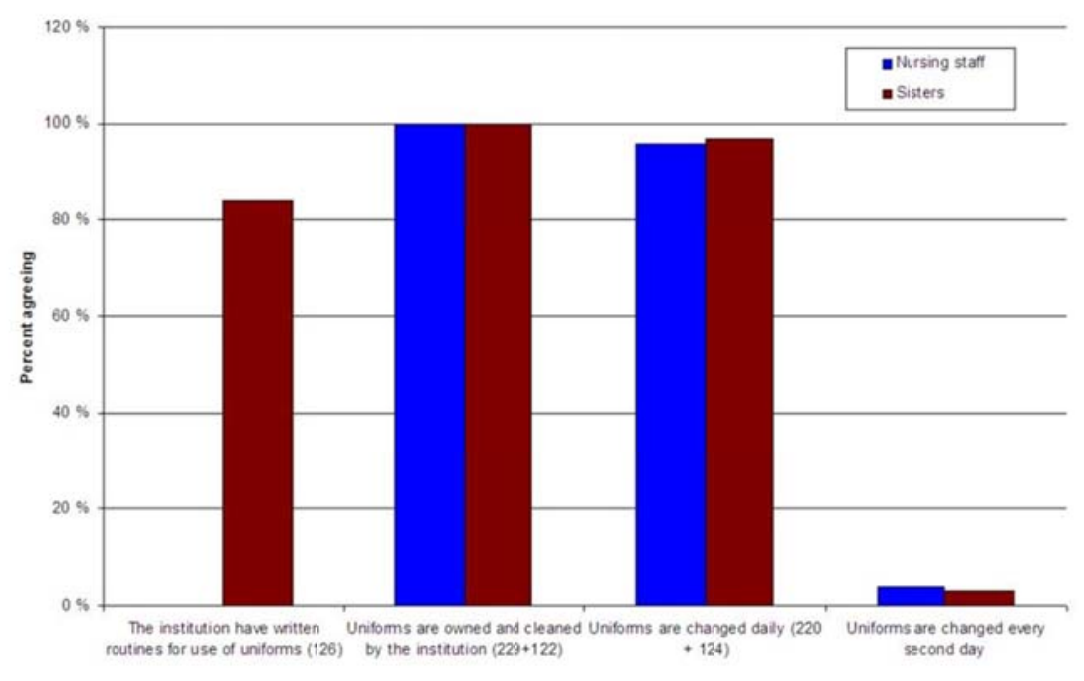

Figure 3. The use of uniforms in the nursing homes in Oslo

\section{Discussion}

Approximately $0.8 \%$ of the Norwegian population live in nursing homes with complex medical problems, a high age (77\% are 80 years or older with a median age of 84 years), and a high need for assistance for daily living (95\%). Infections are a huge problem since more than $7 \%$ have healthcare- associated infections (HAI). A follow-up study demonstrated significantly reduced physical condition, increased admittance to hospital and death after 30 days among infected than non-infected nursing home patients ${ }^{[41]}$. Thus, HAI cause severe consequences for people living in nursing homes, including debilitation, hospital admission and death.

In this situation, more than $30 \%$ of the staff in nursing homes in Oslo are without health qualifications, as shown by us, and there is a high risk of cross-transmission of infections since $20 \%$ of the nursing staff is working at other health institutions at the same time (part time work) ${ }^{[36]}$. Furthermore, 30\% of nursing homes have no MRSA control policy, and $40 \%$ have even no policy for tracing MRSA infections ${ }^{[36]}$. That infection prevention falls short is also recently shown for Canadian nursing homes ${ }^{[42]}$.

As shown by Dancer and others, a dirty environment is thought to be a factor contributing to higher infection rates in health institutions ${ }^{[2,3,5-8,11-13,24,25]}$. A high standard of cleanliness will therefore help to reduce the risk of cross infection. In a prospective cross-over study with introduction of an additional cleaner into a surgical ward, Dancer et al. found a $32.5 \%$ reduction in levels of microbial contamination at hand-touch sites $(p<0.0001)$, furthermore they demonstrated several indistinguishable MRSA strains from patients which were later found in the environment or on other patients weeks apart, and vice versa ${ }^{[12]}$. Uhlemann et al. recently showed that a high frequency of environmental contamination from carriers may contribute to re-colonization and increased risk of infection, and spread of resistant strains ${ }^{[43]}$.

Most nursing homes in Oslo have written infection control programs that include hand hygiene, floor cleaning and uniform routines; ground pillars for fulfilling standard hygiene in health institutions ${ }^{[35,36,40]}$. However, the implementation and quality of the routines varies, as also demonstrated in this study concerning environmental cleaning. This may partly be due to a low number of educated nurses per ward than reported in earlier studies ${ }^{[36,44]}$. This is a drawback since meeting hygiene challenges in nursing homes requires professionally educated personnel.

The weakness of the present study was that the data were self-reported and could not be controlled by direct observation or additional questions. Furthermore, our informants among the nursing staff were selected in a casual manner by factors like 
the persons being on work that day and the persons that had time to answer. Nursing home personnel without health qualifications did not participate in this study. Those who did the cleaning were not included. They may have been able to answer the questions concerning cleaning procedures more precisely. The institutional manger has the overall responsibility, not sisters nor nursing staff. The validity of the research is strengthened when the sisters and other nursing staff present a congruent perception of the floor cleaning frequencies and wearing of uniforms, as they did in this study.

According to the nursing home guidelines, patients' rooms in nursing homes in Oslo are categorized as medium risk for the transmission of bacteria with a cleaning frequency of 4 days a week (moist mopping twice and dry mopping twice) ${ }^{[40]}$. In this study, $50 \%$ of the patients' rooms were cleaned only 3 days a week, which is not up to the standard set. Nearly $40 \%$ of the rooms were cleaned 5 days a week and approximately $10 \%$ were cleaned 7 days a week. Moist mopping was the most common method for daily cleaning in the nursing homes.

Moist mopping has been recommended as the best practice method for reducing the amount of organic material on the floor, based on the use of microbial growth levels (CFU) on the floor and in the air before and after different washing processes, and by the use of adenosine triphosphate bioluminescence assay (ATP) for assessing the efficacy of daily cleaning practices on organic materials ${ }^{[16-18]}$. In this study, $40 \%$ reported washing the floor with soap and water occasionally. It is likely that this happens when the floor is contaminated by wet material from personal hygiene activities and, as such, is the nursing personnel's responsibility. Furthermore, dry mopping was - in this study- reported as a commonly used method in addition to moist mopping in our nursing homes. Dry mopping is not recommended in healthcare institutions since it may result in the accumulation of biological material and increased numbers of airborne particles in patients' rooms ${ }^{[16-18]}$. It has been shown that the overall best cleaning methods seem to be moist or wet mopping ${ }^{[17,18]}$. In one study, wet scrubbing significantly reduced levels of coagulase-positive staphylococci when, in combination with routine methods, produced an effect that persisted for at least a week ${ }^{[45]}$. Floor cleaning is important concerning infection control, since floors provide a huge reservoir of bacteria ${ }^{[6,9-13,17,18]}$. Different floor cleaning methods have different effects on the reduction of bacteria and organic soil. However, methods and standards for assessing infection risk in the patient's environment are still under discussion, like the use of microbial contamination level, the presence of $S$ aureus, and the presence of organic materials measured by ATP or other methods ${ }^{[5,12,16-20,45,46,47]}$. However, visual assessment has been estimated as a poor indicator of cleaning efficacy ${ }^{[48]}$. The methods of cleaning other surfaces than the floors may also be discussed, like the study of environmental cleaning with premoisted microfiber cloths and the 16-side method which spread bacteria to subsequently cleaned surfaces ${ }^{[49]}$. Other important factors may be the bacterial multiplication in cleaning cloths containing organic materials ${ }^{[50]}$.

Enhanced cleaning of heavily contaminated environmental surfaces may reduce transmission of pathogens such as MRSA, VRE, Acinetobacter baumannii, and Clostridium difficile ${ }^{[3,6,9-12,21,23,51]}$. However, the use of chemical disinfectants in a liquid or gaseous form, or UVC light may have a limited effect on microbes, dependent on for instance the quantity and form of the microbes, the presence of protein, biofilms and organic materials, effect area, and suboptimal cleaning and disinfection routines ${ }^{[9,20-23,25,46,47,51]}$.

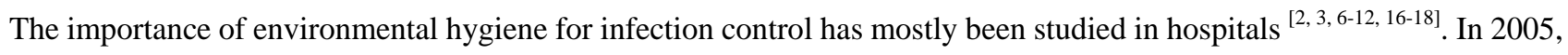
the Britain's largest union, UNISON, drew attention to the dramatic decrease in the numbers of cleaning staff in the country's hospitals and the corresponding rise in the incidence of MRSA ${ }^{[52]}$. The cleaning staff in National Health Service (NHS) facilities had fallen from about 100,000 in 1984 to about 55,000 in 2005. The decrease in staff numbers was due to contracting out of cleaning jobs, poor training, low retention levels due to low wages and dirty hospitals. This was in turn directly thought to contribute to the rise of MRSA ${ }^{[52]}$. In Norway, a rise in hospital infections seemed to be associated with increased workload in the hospital, and was associated with a significant decrease in internal service staff, like the cleaning staff ${ }^{[53]}$. 
Recent intervention studies from nursing homes in UK demonstrated no effect on MRSA prevalence of infection control education and training intervention over a period of 12 months, compared to the control nursing homes ${ }^{[54]}$. Among the ten practice standards observed were: cleanliness of the environment, linen management and hand decontamination. No studies of standard cleaning of uniforms were done, although the colonized staff was suggested to be an unrecognized reservoir of MRSA. The hand hygiene attained the lowest score in all nursing homes audited at baseline, and was, together with decontamination of equipment still deemed poor in the intervention group after 12 months ${ }^{\text {[54] }}$. Increasing the hand washing as a single item among healthcare workers may not always lead to commensurate reductions in staphylococcal infections ${ }^{[55]}$. Therefore, good hand hygiene, combined with the use of clean uniforms and a clean environment may be corner stones to reduce serious infections in long-term care.

Most patients in nursing homes need extended help with the activities of daily living ${ }^{[35,36]}$. Under such situations, the uniforms of the staff may become contaminated during this close contact with the patients and may result in cross-transmitted infections. The duration of patient care activity is strongly associated with the intensity of bacterial contamination on healthcare workers' hands ${ }^{[4]}$. Boyce found that when a patient's immediate environment was heavily contaminated with MRSA, personnel frequently contaminated the front of their uniforms or gowns during activities that did not result in obvious soiling of their clothing ${ }^{[8]}$. The bacteria may survive for many hours on the uniforms as shown by van der Reijnen et al ${ }^{[56]}$. Hambraeus documented in 1973 the transfer of Staphylococcus aureus via nurses' uniforms ${ }^{[57]}$. The infection risks associated with microbial contamination of household linens and clothing like white coats and gowns is recently well reviewed by Bloomfield et al. ${ }^{[58]}$.

Most nursing homes in Oslo City had written routines for the use of uniforms, and the uniforms were owned and cleaned by the institution. This means that the institution takes sole responsibility for the cleanliness of the uniforms. The staff is provided with enough uniforms for a clean outfit per shift. That guarantees a secure procedure regarding uniform treatment in the institution and avoids cleaning uniforms together with private clothes at home. This is in accordance with recommended guidelines ${ }^{[40,59]}$.

\section{Conclusion}

Most nursing homes in Oslo have written routines for floor cleaning and for the use of uniforms, which are important infection control procedures. While the procedures of uniform use and washing were followed by all staff, only $50 \%$ of the institutions seemed to implement the written routines for environmental cleaning. The lack of daily cleaning in nursing homes may be associated with an increased risk of nosocomial infections. Properly personal hygiene and effective cleaning and disinfection are important factors to control infections, like MRSA in nursing homes.

\section{References}

[1] H. Ellis. Florence Nightingale: Creator of modern nursing and public health pioneer. The Journal of Perioperative Practice. 18: 9 Proquest Nursing \& Allied Health Source. 2008. 404p.

[2] S. J. Dancer. Mopping up hospital infection. J Hosp Infect.1999; 43: 85-100. PMid:10549308 http://dx.doi.org/10.1053/jhin.1999.0616

[3] A. Rampling, S. Wiseman, L. Davis et al. Evidence that hospital hygiene is important in the control of methicillin-resistant Staphylococcus aureus, J Hosp Infect. 2001; 49: 109-116. PMid: 11567555 http://dx.doi.org/10.1053/jhin.2001.1013

[4] A. Bhalla, N. J. Pultz, D. Gries et al. Acquisition of nosocomial pathogens on hands after contact with environmental surfaces near hospitalized patients. Infect Control Hosp Epidemiol. 2004; 25:164-7. PMid: 14994944 http://dx.doi.org/10.1086/502369

[5] S. J. Dancer. How do we assess hospital cleaning? A proposal for microbiological standards for surface hygiene in hospitals. J Hosp Infect. 2004; 56:10-15. PMid: 14706265 http://dx.doi.org/10.1016/j.jhin.2003.09.017

[6] M. K. Hayden, M. J. M. Bonten, D. W. Blom, E. A. Lyle, D. A. M. C. van der Vijver, R. A. Weinstein. Reduction in acquisition of vancomycin-resistant enterococcus after enforcement of routine environmental cleaning measures. Clin Infect Dis. 2006; 42:1552-1560. PMid: 16652312 http://dx.doi.org/10.1086/503845 
[7] K. J. Hardy, B. A. Oppenheim, S. Gossain, F.Gao, P. M. Hawkey. A study of the relationship between environmental contaminati on with methicillin-resistant Staphylococcus aureus (MRSA) and patients' acquisition of MRSA. Infect Control Hosp Epidemiol. 2006; 27:127-32. PMid: 16465628 http://dx.doi.org/10.1086/500622

[8] J. M. Boyce. Environmental contamination makes an important contribution to hospital infection. J Hosp Infect. 2007; 65: 50-54. http://dx.doi.org/10.1016/S0195-6701(07)60015-2

[9] B. C. Eckstein, D. A. Adams, E. C. Eckstein, et al. Reduction of Clostridium difficile and vancomycin-resistant Enterococcus contamination of environmental surfaces after an intervention to improve cleaning methods. BMC Infectious Diseases. 2007; 7: 61. PMid:17584935 http://dx.doi.org/10.1186/1471-2334-7-61

[10] E. R. Goodman, R. Platt, R. Bass, A. B. Onderdonk, D. S. Yokoe, S. S. Huang. Impact of an environmental cleaning intervention on the presence of methicillin-resistant Staphylococcus aureus and vancomycin-resistant enterococci on surfaces in intensive care unit rooms. Infect Control Hosp Epidemiol. 2008; 29: 593-599. PMid:18624666 http://dx.doi.org/10.1086/588566

[11] S. J. Dancer. Importance of the environment in meticillin-resistant Staphylococcus aureus acquisition: the case for hospital cleaning. Lancet Infect Dis. 2008; 8:101-113. http://dx.doi.org/10.1016/S1473-3099(07)70241-4

[12] S. J. Dancer, L. F. White, J. Lamb, E. K. Girvan, C. Robertson. Measuring the effect of enhanced cleaning in a UK hospital: a prospective crossover study. BMC Medicine. 2009; 7: 28. PMid:19505316 http://dx.doi.org/10.1186/1741-7015-7-28

[13] J.M. Boyce, G. Potter-Bynoe, C. Chenevert, T. King. Environmental contamination due to methicillin-resistant Staphylococcus aureus: possible infection control implications. Infect Control Hosp Epidemiol. 1997; 18: 622-627. PMid:9309433 http://dx.doi.org/10.1086/647686

[14] A. Kramer, I. Schwebke, G. Kampf G. How long do nosocomial pathogens persist on inanimate surfaces? A systematic review. BMC Infect Dis. 2006; 6:130. PMid:16914034 http://dx.doi.org/10.1186/1471-2334-6-130

[15] S. W. Lemmen, H. Hafner, D. Zolldan, S. Stanzel, R.Lutticken. Distribution of multi-resistant Gram-negative versus Grampositive bacteria in the hospital inanimate environment. J Hosp Infect. 2004; 56:191-197. PMid:15003666 http://dx.doi.org/10.1016/j.jhin.2003.12.004

[16] B. M. Andersen, R. T. Røed, N. Solheim, F. Levy., A. Bratteberg, K. Kristoffersen, I. Moløkken. Air quality and microbial contamination in operation rooms with and without laminar air flow. Tidsskr Nor Lægeforen. 1998; 20: 3148-51.

[17] B. M. Andersen, N. Solheim, Kruger, F. Levy, K. Sogn, I. Moløkken. Floor cleaning in patient rooms. Tidsskr Nor Lægeforen. 1997; 117: 838-41.

[18] B. M. Andersen, M. Rasch, J. Kvist, et al. Floor cleaning. Effect on bacteria and organic materials in hospital rooms. J Hosp Infect. 2009; 271: 57-65. PMid:19013671 http://dx.doi.org/10.1016/j.jhin.2008.09.014

[19] C. J. Griffith, P. Obee, R. A. Cooper, M. Lewis. The effectiveness of existing and modified cleaning regimes in a Welsh hospital. J Hosp Infect. 2007; 67(6): 352-359. PMid:17655976 http://dx.doi.org/10.1016/j.jhin.2007.05.016

[20] Andersen BM, Bånrud H, Bøe E, Bjordal O, Drangsholt F. Comparison of UVC Light and chemicals for disinfection of surfaces in hospital isolation units. Infect Control Hosp Epidemiol. 2006; 27: 729-735. PMid:16807849 http://dx.doi.org/10.1086/503643

[21] G. L. French, J. A. Otter, K. P. Shannon, N. M. T. Adams, D. Watling, M. J. Parks. Tackling contamination of the hospital enviro nment by methicillin-resistant Staphylococcus aureus (MRSA): A comparison between conventional terminal cleaning and hydrogen peroxide vapour decontamination. J Hosp Infect. 2004; 57: 31-37. PMid:15142713 http://dx.doi.org/10.1016/j.jhin.2004.03.006

[22] B. M. Andersen, M. Rasch, K. Hochlin, F-H. Jensen, P. Wismar, J-E. Fredriksen. Decontamination of rooms, medical equipment and ambulances, using a dry mist of hydrogen peroxide disinfectant. J Hosp Infect. 2006; 62:149-155. PMid:16337307 http://dx.doi.org/10.1016/j.jhin.2005.07.020

[23] J. M. Boyce, N. L. Havill, J. A. Otter et al. Impact of hydrogen peroxide vapor room decontamination on Clostridium difficile environmental contamination and transmission in a healthcare setting. Infect Control Hosp Epidemiol. 2008; 29:723-729. PMid:18636950 http://dx.doi.org/10.1086/589906

[24] S.F. Bradley. Double, double, toilet and trouble: infections still spreading in long-term-care facilities. Infect Control Hosp Epidemiol. 2005; 26: 227-230. PMid:15796272 http://dx.doi.org/10.1086/502531

[25] H. M. Wu, M. Fornek, K. J. Schwab, et al. A norovirus outbreak at a long-term-care facility: the role of environmental surface contamination. Infect Control Hosp Epidemiol. 2005; 26: 802-810. PMid:16276954 http://dx.doi.org/10.1086/502497

[26] Y. Aoki, A. Suto, K. Mizuta, T. Ahiko, K. Osaka,Y. Matsuzaki. Duration of norovirus excretion and the longitudinal course of viral load in norovirus-infected elderly patients. J Hosp Infect. 2010; 75: 42-46. PMid:20304524 http://dx.doi.org/10.1016/j.jhin.2009.12.016

[27] C. L. Richards. Infections in long-term-care facilities: screen or clean? Infect Control Hosp Epidemiol. 2005; 26: 800-801. PMid: 16276953 http://dx.doi.org/10.1086/502496 
[28] C. Hughes, M. Smith, M. Tunney. Infection control strategies for preventing the transmission of methicillin-resistant Staphylococcus aureus (MRSA) in nursing homes for older people. Cochrane Database of Systematic Reviews. $2010 ; 1$.

[29] E. I. Best, W. N. Fawley, P. Parnell, et al. The potential for airborne dispersal of Clostridium difficile from symptomatic patients. Clin Infect Dis. 2010; 50: 1450-1457. PMid:20415567 http://dx.doi.org/10.1086/652648

[30] H.A. Ludlam, R. L. Swayne, A. M. Kearns et al. Evidence from a UK teaching hospital that MRSA is primarily transmitted by the hands of healthcare workers. J Hosp Infect. 2010; 74:296-299. PMid:20153081 http://dx.doi.org/10.1016/j.jhin.2009.10.008

[31] J. F. Gehanno, A. Louvel; M. Nouvellon, J. F. Caillard, M. Pestel-Caron. Aerial dispersal of meticillin-resistant Staphylococcusaureus in hospital rooms by infected or colonised patients. J Hosp Infect. 2009; 71: 256-262. PMid:19162372 http://dx.doi.org/10.1016/j.jhin.2008.11.015

[32] W. C. Albrich, S. Harbarth. Health-care workers: source, vector, or victim of MRSA? Lancet Inf Dis. 2008 ; 8: $289-301$. http://dx.doi.org/10.1016/S1473-3099(08)70097-5

[33] S. Chang, A. K. Sethi, U. Stiefel, J. L. Cadnum, C. J. Donskey. Occurrence of skin and environmental contamination with methicillin - resistant Staphylococcus aureus before results of polymerase chain reaction at hospital admission become available. Infect Control Hosp Epidemiol. 2010; 31: 607-612. PMid:20397963 http://dx.doi.org/10.1086/652775

[34] B. M. Andersen, T. Tollefsen, B. Seljordslia, et al. Rapid MRSA test in exposed persons: Costs and savings in hospitals. J Infection. 2010; 60: 293-299. PMid:20122959 http://dx.doi.org/10.1016/j.jinf.2010.01.008

[35] I. Sie, M. Thorstad, B. M. Andersen. Infection control and hand hygiene in nursing homes in Oslo, Norway. Tidsskr Nor Legeforen. 2008; 128: 1528-30. PMid:18587461

[36] I. Sie, M. Thorstad, B. M. Andersen. Infection control and methicillin-resistant Staphylococcus aureus in nursing homes in Oslo. J Hosp Infect. 2008; 70: 235-40. PMid:18786745 http://dx.doi.org/10.1016/j.jhin.2008.06.009

[37] B. M. Andersen, M. Rasch, G. Syversen. Is an increase of MRSA in Oslo, Norway, associated with changed infection control policy? J Hosp Infect. 2007; 55: 531-8.

[38] H. F. L. van der Werff, T. W. Steen, K. M. K. Garder et al. An outbreak of MRSA in a nursing home in Oslo. Tidsskr Nor Legeforen. 2008; 128: 2734-2737. PMid:19079422

[39] Norwegian Department of Health. (Forskrift 17.juni 2005 nr.610). Infection control in healthcare. Oslo. 2005.

[40] Oslo City Public Health. Infection control in nursing homes in Oslo. 2001.

[41] A. M. Koch, H. M. Eriksen, P. Elstrøm, P. Aavitsland, S. Harthug. Severe consequences of healthcare-associated infections among residents of nursing homes: a cohort study. J Hosp Infect. 2009; 71:269-274. PMid:19147254 http://dx.doi.org/10.1016/j.jhin.2008.10.032

[42] D.E. Zoutman, B.D. Ford, J. A. Gauthier. A cross-Canada survey of infection prevention and control in long-term care facilities. Am J Infect Control. 2009; 37: 358-363. PMid:19217188 http://dx.doi.org/10.1016/j.ajic.2008.10.029

[43] A-C Uhlemann, J. Knox, M. Miller, et al. The environment as an unrecognized reservoir for community-associated methicillin resistant Staphylococcus aureus USA300: A case-control study. PloS One/www.plosone.org. 2011. PMid:21818321 http://dx.doi.org/10.1371/journal.pone.0022407

[44] The Norwegian Directorate of Health and Welfare. Plan for recruiting health- and social- workers, 2003-2006.Report no. 1, 2004.

[45] L. F. White, S.J. Dancer, C Robertson. A Microbiological evaluation of hospital cleaning methods. Int J Environ Health Res. 2007;17: 285-295. PMid:17613092 http://dx.doi.org/10.1080/09603120701372433

[46] L. F. White, S.J. Dancer, C Robertson. J. McDonald. Are hygienie standards useful in assessing infection risk? Am J Infect Control. 2008; 36: 381-384. PMid:18538706 http://dx.doi.org/10.1016/j.ajic.2007.10.015

[47] J.M. Boyce, N.L. Havill, D.G. Dumigan, M. Golebiewski, O. Balogun, R. Rizavani. Monitoring the effectiveness of hospital cleaning practices by use of an adenosine triphosphate bioluminescence assay. Infect Control Hosp Epidemiol. 2009; 30: 678-684. PMid:19489715 http://dx.doi.org/10.1086/598243

[48] R.E.Malik, R.A. Cooper, C.J. Griffith. Use of audit tools to evaluate the efficacy of cleaning systems in hospitals. Am J Infect Control. 2003; 31:181-187. PMid:12734526 http://dx.doi.org/10.1067/mic.2003.34

[49] L. K. Bergen, M. Meyer, M. Høg, B. Rubenhagen, L.P. Andersen. Spread of bacteria on surfaces when cleaning with microfibre cloths. J Hosp Infect. 2009; 71: 132-137. PMid:19108933 http://dx.doi.org/10.1016/j.jhin.2008.10.025

[50] S. Bartz, A.C. Ritter, E.C. Tondo. Evaluation of bacterial multiplication in cleaning cloths containing different quantities of organic matter. J Infect Dev Ctries. 2010; 4: 566-571. PMid:21045369

[51] F.A. Manian, S. Griesenauer, D. Senkel, J.M. Setzer, S.A. Doll, A.M. Perry, et al. Isolation of Acinetobacter baumannii-complex and methicillin-resistant Staphylococcus aureus from hospital rooms following terminal cleaning and disinfection: can we do better? Infect Control Hosp Epidemiol. 2011; 32: 667-672. PMid:21666397 http://dx.doi.org/10.1086/660357

[52] B. Smith. Britain: rise in "superbug” cases linked to decrease in hospital cleaning staff. World Socialist Web Side; wsws.org. 22. 2005 January. 
[53] B.M. Andersen, M. Rasch, K. Hochlin, T. Tollefsen, L. Sandvik. Hospital-acquired infections before and after healthcare reorganization in a tertiary university hospital in Norway. J Pub Health. 2009; 7: 1-7.

[54] N. S. Baldwin, D. F. Gilpin, Tunney D, et al. Cluster randomized controlled trial of an infection control education and training intervention program focusing on methicillin-resistant Staphylococcus aureus in nursing homes for older people. J Hosp Infect. 2010; 76: 36-41. PMid:20451294 http://dx.doi.org/10.1016/j.jhin.2010.03.006

[55] C. B. Beggs, S. J. Shepherd, K. G. Kerr. Increasing the frequency of handwashing by healthcare workers does not lead to commensurate reductions in staphylococcal infection in a hospital ward. BMC Infect Dis. 2008; 8: 114. PMid:18764942 http://dx.doi.org/10.1186/1471-2334-8-114

[56] W.A. van der Reijden, J.M. Heijers, C.M. Vandenbroucke-Grauls, J.J. de Soet. Survival of bacteria on uniforms in relation to risk management in dental clinics. J Hosp Infect. 2009; 73: 283-285. PMid:19781812 http://dx.doi.org/10.1016/j.jhin.2009.08.003

[57] A. Hambraeus. Transfer of Staphylococcus aureus via nurses' uniforms. Journal of Hygiene. 1973; 71:799-814. http://dx.doi.org/10.1017/S0022172400023068

[58] S. F. Bloomfield, M. Exner, C. Signorelli, K. J. Nath, E. A. Scott. The infection risks associated with clothing and household linens in home and everyday life settings, and the role of laundry. International Scientific Forum on Home Hygiene [Internet]. 2011 April; 1-47. Available from: http://www.ifh.homehygiene.org

[59] B. M. Andersen. Handbook in hygiene and infection control. Nursing homes and long-term-care facilities. Ullevål University Hospital, Oslo. 2006. 